\title{
Boerhaave and the Flight from Reason in Medicine
}

\author{
HAROLD J. COOK
}

Boerhaave's is a name to reckon with. It is invoked often in the history of medicine and science as if there were a widespread understanding of his views, his accomplishments, and his causal influence. Our "knowledge" about Boerhaave's importance, however, is often familiarity with the icon rather than the person. The mythology makes him into perhaps the greatest rational systematist of modern medicine, providing the foundation for eighteenth-century academic medicine. Even less-exalted claims tend to emphasize his singular importance. If we treat him instead as a very thoughtful and articulate participant in the intellectual culture of his day, we can not only show his debt to others, we can, more importantly, draw some conclusions that show his partisanship for a particular outlook.

Rather than trying to reconcile reasoned theory with sensory experience, Boerhaave placed all his confidence in the latter; rather than attempting to unify knowledge of mind and body, he declared that the physician needed only to understand the latter. In his religion as in his medicine he trusted experience rather than reason, shedding discussion of doctrine and its consequences. Whatever he may have believed when he prayed, Boerhaave's medical teachings explicitly avoided any reference to immaterial powers, whether they be faculties or a soul, in favor of that which could be known through the senses. Accordingly, in contrast to medical professors like Georg Ernst Stahl, he separated his religious views from his medical ones. Moreover, given his refusal to comment at length on the relationship between the rational soul (or mind) and the body, materialists such as Julien Offray de La Mettrie could claim him as

I would like to thank Paul Wood and Roger Emerson for inviting me to write about Boerhaave for a conference on the medical and scientific Enlightenment, held at Edinburgh in 1998, and for the comments of all the participants; and thanks especially to the anonymous referees of an earlier version of this manuscript. 
one of their own. Examined from this point of view, his work points to one of the main sources of tension in academic medicine at the beginning of the eighteenth century: would it lead people away from a full account of humans into the merely useful knowledge of the corporeal body?

Until recently, most accounts of Boerhaave have taken their direction from the Oratio academica: In memoriam Hermanni Boerhaavii, delivered by his colleague Albert Schultens in November 1737 and published soon thereafter. In addition to his personal acquaintance with Boerhaave, Schultens had access to Latin notes about his life written by Boerhaave himself shortly before his death, apparently with the forthcoming occasion in mind. Schultens printed Boerhaave's words in large italics, and they were subsequently gathered together as the so-called Commentariolus. ${ }^{1}$ Schultens's oration was a paean to the good character and powerful intellect of his former friend. His Latin account served as the basis for the English biographical essays by Samuel Johnson and by Boerhaave's student and admirer William Burton. ${ }^{2}$ They, too, saw him in heroic terms. Until recently, most English-language accounts derived from them. Dutch historians of medicine tended to reinforce the view of Boerhaave as the highest pinnacle of Enlightenment medicine. For instance, in 1968 the professor of anatomy at the University of Leiden, J. Dankmeijer, gave an address on Boerhaave asking "Is Boerhaave's Fame Deserved?"- to which he emphatically answered "yes." More significantly, Gerrit Lindeboom's major English-language study of Boerhaave, also from 1968, is a revival of Schultens's enthusiasm in modern dress. For Lindeboom, Boerhaave brought order to chaos: "before Boerhaave's appearance practical medicine was in a state of confusion and often not more than a precarious empiricism," or worse; "hence," he concludes, "there was a lifetime's work for a man with keen insight into the momentous needs of theoretical and practical medicine and of medical education. Such a man made his appearance in Boerhaave." Until the end of the 1960s, then, the major accounts in English and Dutch stressed Boerhaave's superb character and his rational intellect. ${ }^{5}$

1. This first appeared as an appendix to William Burton's work: see below.

2. See D. A. K. Black, "Johnson on Boerhaave," Med. Hist., 1959, 3: 325-29; and see below for Burton.

3. J. Dankmeijer, "Is Boerhaaves faam gerechtvaardigd?" in F. L. R. Sassen and idem, Herman Boerhaave 1668/1968 (Leiden: Universitaire Pers, 1968), pp. 23-39; idem, "Is Boerhaave's Fame Deserved?" in Boerhaave and His Time, ed. Gerrit A. Lindeboom (Leiden: E. J. Brill, 1970), pp. 17-30.

4. Gerrit A. Lindeboom, Herman Boerhaave: The Man and His Work (London: Methuen, 1968), p. 9.

5. My impression is that this is true of the German historiographic tradition as well, but I await the work of others on it. 
French historians, on the other hand, treated Boerhaave as of far more ordinary mental capacity. Charles Daremberg, for example, in his notable nineteenth-century Histoire des sciences médicales, remarked that "in the Aphorisms and in the Institutes there is nothing profound nor anything beyond the ordinary reach of the human mind; neither is the form new nor the doctrine sublime and innovative; it seems to me that the commentary of his disciple Van Swieten is far better than the text of his master." Given his assessment of Boerhaave's intellect as rather ordinary, Daremberg acerbically dismissed Schultens's account as "tiring due to a convulsive and gasping enthusiasm. The oration begins, proceeds, and concludes with exclamation points." Daremberg preferred the account of Boerhaave written by the infamous La Mettrie. ${ }^{8}$ La Mettrie relied on Schultens for biographical information, but in treating his professor's ideas as materialist he has provoked many Boerhaave enthusiasts ever since. ${ }^{9}$

Since the 1970 s, attempts have been made to find other ways to account for Boerhaave's importance, with little success. For instance, there is an oft-repeated story to confirm his fame: that a letter from China arrived in his hands addressed merely "to Mr Boerhaave Physician in Europe." This story, however, told since at least 1802, when Antoine François de Fourcroy inserted it in one of his lectures on chemistry at the Jardin des Plantes in Paris, probably originated with a letter from the Dey of Tunisia that hardly needed an address, forwarded as it was to The Hague via the diplomatic pouch of the Dutch ambassador. ${ }^{10}$ The notion that he became a professor at the famous medical school of Leiden because his genius was recognized has been demolished by Maarten Ultee's account of how he finally obtained the post. ${ }^{11}$ Boerhaave has also been hailed as the father of academic clinical teaching ${ }^{12}$ - but as Harm Beukers has shown, he was neither an innovator of this practice, nor an especially energetic practitioner of it in his public role as a medical

6. Charles Daremberg, Histoire des sciences médicales (Paris: Baillière, 1870), 2: 890: "Dans les Aphorismes et dans les Institutions il n'y a ni profondeur, ni rien qui dépasse la mesure ordinaire de l'esprit humain; ni la forme n'est nouvelle, ni la doctrine n'est sublime et inouie; il me semble même que le commentaire du disciple Van Swieten vaut beaucoup mieux que le texte du maitre." It was Daremberg to whom Dankmeijer addressed himself.

7. Ibid., p. 889 n. 3.

8. Ibid., p. 889: La Mettrie's Vie "est beaucoup plus calme et plus instructive."

9. For example, see Lindeboom, Herman Boerhaave (n. 4), pp. 238-39.

10. Otto M. Marx, "M. Boerhaave en Europe: The Origins of an Anecdote Explained?" $J$. Hist. Med. All. Sci., 1968, 23: 389.

11. Maarten Ultee, "The Politics of Professorial Appointment at Leiden, 1709," Hist. Univ., 1990, 9: 167-94.

12. For a good summation of this view, see Guenter B. Risse, "Clinical Instruction in 
professor at Leiden. ${ }^{13}$ Then there is the approach emphasizing Boerhaave's physiological theories. Called a "mechanist," or a "systematist," or praised for his account of a physiology of fluids and solids, he is held up as the formulator of the major medical doctrine of the eighteenth century. ${ }^{14}$ Yet the physiological theory associated with Boerhaave is probably best characterized as one shared widely with others: for example, the notion that many organs of the body were composed of fluids and solids owes much to others-such as Marcello Malpighi's investigations into glands, and the techniques of anatomical injection developed by Frederick Ruysch, among others. ${ }^{15}$

Boerhaave's famous disciple Albrecht von Haller called him communis Europae praeceptor ("teacher of all Europe"). Especially the commentaries on Boerhaave's Institutes by Haller and those on his Aphorisms by Gerhard van Swieten gained much fame and wide circulation. But as Willem Frijhoff has shown, the period of Boerhaave's professorships shows a decline both in the absolute number of foreigners who took their medical degrees at Leiden and in the percentage of foreigners who studied at Leiden rather than at other Dutch universities. Frijhoff has therefore quite sensibly argued that Boerhaave's considerable reputation may have owed more to the changes in Dutch academic medicine advanced in the seventeenth century than to his personal genius. ${ }^{16}$ Some of Boerhaave's students, for instance, began formal medical instruction at Edinburgh, Vienna, and Göttingen, and attributed their own importance in part to the teachings of their professor rather than to other people and events (such as those who established the schools). They continued to foster a medical outlook associated with the Leiden school even before Boerhaave's time, one growing in importance in the eighteenth century: the ancient ideal of the learned physician as the judge of each individual's unique life circumstances was fading in light of surgical and medical intervention and the advancement of the profession within the state. ${ }^{17}$ In other

Hospitals: The Boerhaavian Tradition in Leyden, Edinburgh, Vienna and Pavia," Clio Med., 1987/88, 21: 1-19.

13. Harm Beukers, "Clinical Teaching in Leiden from Its Beginning until the End of the Eighteenth Century,” Clio Med., 1987/88, 21: 139-52.

14. See Lester S. King, The Medical World of the Eighteenth Century (Chicago: University of Chicago Press, 1958), pp. 59-93.

15. Edward G. Ruestow, "The Rise of the Doctrine of Vascular Secretion in the Netherlands," J. Hist. Med. All. Sci., 1980, 35: 265-87.

16. Willem Th. M. Frijhoff, La Société Néerlandaise et ses gradués, 1575-1814: Une recherche sérielle sur le statut des intellectuels à partir des registres universitaires (Amsterdam: APA-Holland University Press, 1981), pp. 103-7.

17. As Frijhoff puts it: "laissant derrière lui l'ancien idéal de formation humaine et 
words, it was the viewpoint of Dutch medicine, which Boerhaave happened to be in a position to communicate, that made him famous, rather than his character or intellect.

Similarly, Andrew Cunningham has advanced the argument that Boerhaave was a representative of Dutch medical teaching, which Cunningham describes as clear, industrious, and tolerant. Boerhaave's teachings were adopted at Edinburgh especially for their irenicism, Cunningham argues. He had the ability to combine various medical arguments into an eclectic but unified system that brought peace of mind rather than divisive disputes. This suited the need to dampen the formerly bitter disputes between physicians, surgeons, and apothecaries in Edinburgh. For Cunningham, Boerhaave's contributions resulted from his search for peace of mind, which in turn stemmed from his religious training: "Boerhaave's medicine was his theology-itself built round a desperate desire for peace of mind-in another domain." 18 Indeed, Boerhaave, like many ancient and early modern philosophers, made tranquility of mind a chief goal of knowledge. Yet, to the extent that theology is equivalent to teachings of religious doctrine, he rejected a theological outlook. The sources for his quest may not have been in his theology; in any case, in his medical works he held back virtually all suggestions of his religious outlook. He apparently remained privately religious, but in his religion as in his medicine he came to denounce teachings built on rational arguments. As in his medicine, so in his religion: he was no theological irenic, but rejected doctrine in favor of experience, wherever it might lead.

A reexamination of the evidence concerning what Boerhaave thought about the use of reason, then, can yield a deeper understanding of his outlook and the extent to which it represents a particular school of thought. It can be shown that he went through an intellectual conversion in the early 1690s, before he became a physician, that turned him against the power of reason to examine the causes of things. While there remain only hints about the sources of this conversion, the consequences can be shown. Following this fundamental shift, the kind of intellectual problems he left silently aside in his academic medicine turn out to be as

générale, il s'engage peu à peu sur le chemin de la formation professionnelle" (ibid., p. 105). Also see Harold J. Cook, "Good Advice and Little Medicine: The Professional Authority of Early Modern English Physicians," J. Brit. Stud., 1994, 33: 1-31.

18. Andrew Cunningham, "Medicine to Calm the Mind: Boerhaave's Medical System, and Why It Was Adopted in Edinburgh," in The Medical Enlightenment of the Eighteenth Century, ed. Andrew Cunningham and Roger French (Cambridge: Cambridge University Press, 1990), pp. 40-66; quotation on p. 47. 
significant as the ones on which he commented. Boerhaave strove to simplify the complexities of medicine, not by relying on rational principles and a system built on them, but by relying on sense experience and classifications based on appearances. The upshot of his struggle for peace of mind became a solution for the problems of medicine, but in rejecting reason he rejected rational theology as well as dogmatic medicine. This also makes sense out of accounts of Boerhaave both as a clear and judicious thinker and as lacking original genius.

\section{Reason and the Passions}

In classical philosophy and its offshoots, "reason" was yoked to the "passions." While reason was the highest faculty of the mind or soul (anima) and separated humans from the unreasoning beasts, the passions linked the soul to the body and were possessed by animals as well as humans. ${ }^{19}$ To most philosophers-especially the Christian scholars who took up Platonic and Aristotelian teachings-the ability to follow "the good," morally and healthfully, lay in the ability to use reason to control or temper the passions. For most early modern philosophers and physicians, both peace of mind and good health derived from placing a check on the passions. Some challenged the orthodox view, however. By the mid-eighteenth century, for instance, David Hume argued that morally dutiful or admirable conduct had its source in the passions rather than reason, while Immanuel Kant thought that such views undermined morality, and so shaped his moral philosophy to reflect the classical ideal in which reason commanded. Some decades before Hume, Boerhaave had also arrived at the opinion that reason could not-perhaps even should not-control the passions. Since all knowledge of the world came from our sense impressions alone, reason could only calculate material cause and effect, neither understanding the foundations of things nor controlling them. In one of the crucial debates of the period, Boerhaave had taken sides.

The intellectual culture of the Netherlands in which Boerhaave came of age was replete with discussions of reason and the passions. The famous Erasmus of Rotterdam, for instance, discussed them in his early Enchiridion militis Christiani (1503), in which he urged his readers to prepare to make war on themselves. If left unguarded, the passions might rise up and overthrow the king of the soul, reason. To hold this

19. For a good summary, see Katharine Park, "The Organic Soul," in The Cambridge History of Renaissance Philosophy, ed. Charles B. Schmitt (Cambridge: Cambridge University Press, 1988), pp. 464-84. 
potential internal civil war in check, as well as to wage it successfully if necessary, "the chief hope of victory lies in your knowing yourself as thoroughly as possible. ${ }^{20}$ Reason had to guard against the assaults of the passions and appetites, of which "there are none so turbulent that they cannot be curbed by rational control or channeled in the direction of virtue." ${ }^{11}$ Hence, the only true path to virtue lay first in knowing yourself, and second in acting "not according to the passions, but the dictates of reason." ${ }^{22}$ Erasmus's rough contemporary, Juan Luis Vives, who spent many years in the low countries, set out a more Aristotelian view on the passions of the soul in the third book of his De anima et vita (1538), arguing that the passions were not all bad but had been given to animals as "spurs to move the soul this or that way, reins to restrain it from running into the harmful." ${ }^{.3}$ If the passions are left unchecked, however, we "lose control of ourselves, and thoughtlessly throw ourselves into a storm to be carried away wherever it pleases it rather than us. ${ }^{\prime 24}$ Only through the use of good judgment based on reason can people attain some personal freedom to move toward the good. The famous Flemish scholar Justus Lipsius revived Stoic doctrines on reason and the passions with his De constantia of 1584, arguing that all passions were harmful and upset the soul's equilibrium. Inner peace could be found only by remaining steadfast in the face of the world's storms. ${ }^{25}$

Medical teachings, too, dealt explicitly with the fundamental dialectic of reason and passion. By either tempering or conquering the passions by the use of reason, one would be able to live not only morally but healthfully. If people managed their lives according to their own constitution and circumstances (regulating diet and exercise, the situation of their abode, and other such matters, including choosing friends and companions carefully), and followed the established course of life carefully and regularly, then health could be maintained, or even restored (if

20. Erasmus, The Enchiridion of Erasmus, trans. Raymond Himelick (Gloucester, Mass.: Peter Smith, 1970), pp. 59-63; quotation on p. 63.

21. Ibid., p. 68.

22. Ibid., p. 70.

23. Juan Luis Vives, The Passions of the Soul: De anima et vita. Book 3. Trans. Carlos G. Noreña (Lewiston, N.Y.: Edwin Mellen Press, 1990), pp. 4-5. I have substituted "passions" for Noreña's anachronistic "emotions."

24. Ibid., p. 6. Also see Carlos G. Noreña, Juan Luis Vives and the Emotions (Carbondale: Southern Illinois University Press, 1989), esp. pp. 141-58.

25. See Jason Lewis Saunders, Justus Lipsius: The Philosophy of Renaissance Stoicism (New York: Liberal Arts Press, 1955); Martin van Gelderen, "The Machiavellian Moment and the Dutch Revolt: The Rise of Neostoicism and Dutch Republicanism," in Machiavelli and Republicanism, ed. Gisela Bock, Quentin Skinner, and Maurizio Viroli (Cambridge: Cambridge University Press, 1990), pp. 205-23. 
disease had occurred because of irregularities). Yet all physicians (as well as philosophers and theologians) knew how difficult it was to regulate the unruly passions by the use of reason. Accordingly, Galen himself had written a treatise On Moral Character in which he described how to cultivate obedience in the soul through a series of exercises that included pitting one passion against another. ${ }^{26}$ By such techniques, and by following the learned advice of educated physicians-rooted in reason as it was-each person could develop and follow a regimen appropriate for his or her own temperament and way of life that, if followed, would preserve health and prolong life. Following reason rather than one's passions prevented disease, and could even help to cure.

Not surprisingly, then, when Boerhaave's contemporaries praised him they stressed his ability to command his passions. For example, Boerhaave's English student Burton followed Schultens in writing fulsome praise of his professor, not only for his immense learning, but also for his personal virtues (to which Burton devoted thirty pages). Boerhaave's virtues included steady hard work, love of country yet openness to large numbers of foreign students, domestic felicity and great wealth, and, above all, Christian patience. He was good and helpful to everyone, a sincere friend, above calumny, courteous, and so on. He exhibited all the outward characteristics of a good Christian. Indeed, the high points of his person were two: his learning, and his earnest and regular devotions every morning. "To this [latter] alone he attributed the conquest he had gained over the irascible passions. ${ }^{.27}$

Burton's comment is significant on at least two grounds: he writes of Boerhaave's "conquest" of the passions, and in doing so he uses a technical term, the "irascible passions." In discussing the passions, it had long been commonplace to divide them into the concupiscible (simpler and desiring) and the irascible (more complex and powerful) ${ }^{28}$ Burton's comment that Boerhaave conquered his most complex and powerful passions is, therefore, a clear statement of very high praise. It is further loaded with significance, however, when he comments that Boerhaave himself attributed this conquest not to reason but to regular morning

26. Galen distinguishes two kinds of error: "error arises from a false opinion, but passion from an irrational power within us which refuses to obey reason; commonly both are called errors in a more generic sense" (Galen, On the Passions and Errors of the Soul, trans. Paul W. Harkins [Columbus: Ohio State University Press, 1963], p. 28). Galen summarizes his lost treatise On Moral Character on pp. 47-69.

27. William Burton, An Account of the Life and Writings of Herman Boerhaave (London: $\mathrm{H}$. Lintot, 1746), p. 53.

28. William Webster Newbold, ed., The Passions of the Mind in General, by Thomas Wright: A Critical Edition (New York: Garland, 1986), pp. 18, 22. 
prayer. This statement that Boerhaave had conquered his irascible passions not by making war on himself, nor by buttressing the spark of reason against the stealth and power of the animal passions, but rather through some kind of unspecified power of prayer, is an unusual and important clue about his lack of confidence in the power of reason. The evidence for Boerhaave's view of his conquest of the passions is confirmed elsewhere. In the Commentariolus, Boerhaave stated that at every opportunity he professed that tranquility of mind came only through the life and words of Jesus Christ. He always told his friends, he wrote, that peace of mind can come only from observing Moses' doctrine of having a sincere love of God and humanity, while nothing outside of scripture could bring peace of mind..$^{29}$ That his was not a religion of doctrine was reinforced by his reiteration that he worshipped the living God, only wanting to understand that which God knew about himself (from the book of nature), being content with nothing more than was requisite lest he err in idolatry. In this he rested, seeking no rational investigation. With this one supreme law one should be content. ${ }^{30}$

\section{The Flight from "Reason"}

Boerhaave was quite aware of the position he was taking, which developed explicitly sometime after 1690 . He had intended to follow his father into the ministry. The Rev. Jacobus Boerhaave made sure that his son learned both Latin and Greek fluently before adolescence; he also instructed Herman in Hebrew and other biblical languages. As a result, the young Boerhaave had great success in Latin School, earning first prizes in the promotion competitions. ${ }^{31}$ At the University of Leiden, where he matriculated in philosophy and theology in 1684, he continued to progress in his study of languages as well as philosophy. He held an unusually high number of disputations as a student-five in all-showing how impressed his professors were with their learned pupil. The first of his orations was

29. "Omni opportunitate profitebatur disciplinam, quam Jesus Christus ore \& vita expressit, unice tranquillitatem dare menti. Semperque dixit amicis, pacem animi haud reperiundam nisi in magno Mosis preacepto de sincero amore Dei \& hominis, bene observato. Neque extra sacra monumenta uspiam inveniri, quod mentem serenet" (quoted in Lindeboom, Herman Boerhaave [n. 4], p. 383); my paraphrase carries a somewhat different emphasis than Lindeboom's translation.

30. "Deum pius adoravit, qui est. Intelligere de Deo unice volebat id, quod Deus de se intelligit. Eo contentus ultra nihil requisivit, ne idololatria erraret. In voluntate Dei sic requiescebat, ut illius nullam omnino rationem indagandam putaret. Hanc unice supremam omnium legem esse contendebat, deliberata constantia perfectissime colendam" (ibid., p. 383).

31. Ibid., p. 17. 
on the natural-philosophical subject of cohesion, but in the next academic year (1687-88) he delivered a three-part oration at the end of each of the terms, on De mente humana, which necessarily dealt with reason and the passions. In the next year, 1690, he was invited to present a special academic oration, for which he received a gold medal-only the second time ever that a gold medal was presented by the curators of Leiden university to a student. The thesis for which he earned the gold medal also dwelt on a deep and difficult subject involving reason and the passions: that of human happiness. Titled Oratione sententiam Epicuri de summo homin. bono enarranti, it has been recently translated as "Oration on the Thesis That Cicero's Interpretation of Epicurus's Maxim on the Highest Human Good Is Right."32 It defended the generally Stoic position that reason needed to conquer the passions instead of indulging them, as the Epicureans were accused of doing. Moreover, in December 1690 Boerhaave defended a thesis for the doctorate in philosophy and the masters of liberal arts on the distinction between mind and body, severely criticizing the monist views of Epicurus, Hobbes, and Spinoza. ${ }^{33}$ There is, then, plenty of evidence that he was the star pupil of his generation of Leiden students, and that this standing came not only from his complete command of Latin and Greek and the clarity of his own Latin prose but also from his explicit attempts to deal with the crucial question of the relationship between reason and the passions, in which he defended the common opinion that reason remained separate from the body and could and should control its passions.

At some point in the next few years, however, the young Boerhaave moved away from his confidence in the power of reason. We do not know exactly what prompted his new journey. It may have been his studies in theology, which he continued toward the goal of a doctorate. In the seventeenth century, pietism had become a possible option within Dutch Reformed thinking, and it gained strength later in the century. ${ }^{34}$ Perhaps his father had been a party to discussions of pietism as an alternative to rational theology. At the same time, one of the most powerful intellectual debates within Dutch Calvinism during his youth centered on the views of Joannes Coccejus, professor of theology at Leiden university. The

32. E. Kegel-Brinkgreve and A. M. Luyendijk-Elshout, trans., Boerhaave's Orations, Sir Thomas Browne Institute (Leiden: E. J. Brill/Leiden University Press, 1983), pp. 18-53.

33. Boerhaave's graduation thesis of 21 December 1690, De distinctione mentis a corpore, arguing against Epicurus, Hobbes, and Spinoza (among others), has not been subsequently printed, and I have not seen a copy; for information on its contents, see Lindeboom, Herman Boerhaave (n. 4), p. 24; Ferdinand Sassen, Geschiedenis van de Wijsbegeerte in Nederland (Amsterdam: Elsevier, 1959), p. 224.

34. M.J. van Lieburg, "De dichter-medicus Daniel Jonctys (1611-1654): Zijn strijd tegen het bijgeloof en zijn relatie tot Johan van Beverwijk, William Harvey en Daniel Sennert," 
academic revisionism of the Coccejeans argued for the separation of theology from philosophy, and because they therefore rejected Aristotelian terminology in the interpretation of scripture, they sometimes supported new philosophical views, such as Cartesianism. ${ }^{35}$ The only clear testament of Boerhaave himself comes from his Commentariolus, in which he explains that during his theological studies he read the church fathers in chronological order, and became disillusioned with all the disputes based on metaphysical assumptions; he therefore decided to give an oration for his doctorate in theology on why it was that unlearned men had made so many converts to Christianity in the past, while the most modern made so few. ${ }^{36}$

Boerhaave's doubts about reason's need or capacity to control the passions may equally have come from philosophical reflection, however. Since at least the 1620 s, Leiden moral philosophers had developed views running counter to neo-Stoic doctrines. The influential professor of philosophy Franco Burgersdijk took up Plutarch's view that moral virtue was rooted in the passions although guided by reason. His successor, Adriaan Heereboord, set out even stronger arguments about the great importance of the passions in public life. ${ }^{37}$ The brothers De la Court, who studied with Heereboord in their youth, even gave voice to the opinion that as long as they were regulated by law, peoples' pursuit of their own passions would benefit the commonwealth. ${ }^{38}$

Boerhaave may, too, have learned something from Descartes. While Descartes is best known today for famously defining and delineating the

Tijdschrift voor de Geschiedenis der Geneeskunde, Natuurw., Wisk., en Teckniek, 1979, 2: 137-67; idem, "Zeeuwse Piëtisten en de geneeskunde in de eerste helft van de 17e eeuw: Een verkenning van het werk van W. Teellinck en G. C. Udemans," Archief, Jaargang 1987, pp. 63-86; idem, "Religion and Medical Practice in the Netherlands in the Seventeenth Century: An Introduction," in The Task of Healing: Medicine, Religion and Gender in England and the Netherlands, 1450-1800, ed. Hilary Marland and Margaret Pelling (Rotterdam: Erasmus Publishing, 1996), pp. 135-43.

35. Caroline Louise Thijssen-Schoute, Nederlands Cartesianisme (1954; reissued Utrecht: Hes Uitgevers, 1989), pp. 30-34; Theo Verbeek, Descartes and the Dutch: Early Reactions to Cartesian Philosophy, 1637-1650 (Carbondale: Southern Illinois University Press, 1992), p. 87.

36. Lindeboom, Herman Boerhaave (n. 4), pp. 380, 382.

37. H. W. Blom, "Felix qui potuit rerum cognoscere causas: Burgersdijk's Moral and Political Thought," in Franco Burgersdijk (1590-1635): Neo-Aristotelianism in Leiden, ed. Egbert P. Bos and H. A. Krop (Amsterdam: Rodopi, 1993), pp. 119-50, esp. pp. 126-38, 149-50. Also see E. H. Kossmann, "The Development of Dutch Political Theory in the Seventeenth Century," in Britain and the Netherlands, ed. John Selwyn Bromley and Ernst Heinrich Kossmann (London: Chatto and Windus, 1960), pp. 92-98.

38. For several studies on the brothers De la Court, see H. W. Blom and I. W. Wildenberg, eds., Pieter de la Court in Zijn Tijd: Aspecten van een Veelzijdig Publicist (1618-1685) (Amsterdam: APA—Holland University Press, 1986). 
differences between the body and the rational soul, he was also known in Boerhaave's day for his views of the body that limited the power of the rational soul, expressed in his late works: Traité des passions de l'âme (1649), and De homine/De l'homme (1662/1664). "It does not seem to me that the human mind is capable of forming a very distinct conception of both the distinction between the soul and the body and their union" at the same time, Descartes confessed to the Princess Elizabeth. ${ }^{39}$ He nevertheless turned his attention to the relationship between body and reason partly due to Elizabeth's prodding. About the way in which the soul is acted on by the body "I have said hardly anything," he admitted; his first philosophical aim had been "to prove the distinction between the soul and the body, and to this end only the first was useful, and the second might have been harmful." ${ }^{40}$ In the Traité, however, Descartes taught that virtue lay not in making war on the passions with the faculty of reason, but in living "in such a way that his conscience cannot reproach him for ever failing to do something he judges to be the best"; that way, a person will have a tranquil soul, which "the most violent assaults of the passions will never have sufficient power to disturb." ${ }^{11}$ If one pursues this course toward a virtuous life, then the rational faculty or soul will remain free from being a slave to the passions. One can therefore enjoy the pleasures brought by the passions while turning the ills they cause into "a source of joy." ${ }^{2}$ From the Traité and other Cartesian works, then, Boerhaave may have taken several lessons: a rejection of speculation about first causes in favor of investigation of corporeal things; a view that although humans were composed of both body and reason united, given their quite different natures one could not explain how they interacted with one another, but could only observe the interactions; and a view of the passions in which they could not be wholly subjugated by reason. ${ }^{43}$

Any growing doubts about the power of reason Boerhaave may have had must have been reinforced by an unfortunate personal attack on him. He himself merely comments that although he was innocent, he was

39. The Philosophical Writings of Descartes, ed. and trans. John Cottingham, Robert Stoothoff, and Dugald Murdoch, 3 vols. (Cambridge: Cambridge University Press, 1985-91), 3: 22629; quote on p. 227.

40. Ibid., 3: 218

41. Ibid., 1: 382 .

42. Ibid., 1: 404 .

43. For a stronger argument on Boerhaave as a Cartesian, see John P. Wright, "Boerhaave on Minds, Human Beings, and Mental Diseases," Studies in Eighteenth-Century Culture, vol. 20, ed. Leslie Ellen Brown and Patricia B. Craddock (1990):289-302; idem, "Metaphysics and Physiology: Mind, Body, and the Animal Economy in Eighteenth-Century Scotland," Oxford Studies in the History of Philosophy (Studies in the Philosophy of the Scottish Enlightenment), 1 (1990): 251-301. 
implicated in things that created obstacles to his obtaining a position in the church. ${ }^{44}$ Schultens and almost all biographers since have told the story more elaborately. In the spring of 1693 , on his way back to Leiden from Harderwijck, where he had just taken his M.D. degree, he heard several passengers in the canal boat condemning Spinoza. Boerhaave had also condemned Spinozism and Hobbesism and other such doctrines in his orations. But he made a mistake not unknown among arrogant young academics: he asked the other passengers if they had ever actually read anything by Spinoza. This stopped the conversation dead. Someone who had been silently sitting in the corner listening with favor to the previous discussion then asked Boerhaave's name, entering it in his notebook. After Boerhaave and the passengers got out at Leiden, a rumor began circulating that he was a secret Spinozist-which put an end to his chances of advancement in the church. It would also almost certainly have reinforced his doubts about the efficacy of reason to obtain the truth.

Presumably, Boerhaave had gone to take a Harderwijck M.D. degree (it was much less expensive than Leiden's) in order to give medical advice to future parishioners: the combination of some medical study with training for the church was common enough, although few intending theologians went so far as to take a medical doctorate. His patron Johan van den Berg, secretary to the curators of Leiden university, had encouraged his medical studies. Boerhaave later wrote that he studied medicine in the same way he had studied theology, by reading the best authors in chronological order. Perhaps the variety of metaphysical views he encountered in his medical reading also strengthened his doubts about the ability of reason to understand nature. Perhaps some medical outlook changed his mind-as we will see, there were other modern physicians with whom his views shared a great deal. In any case, he soon publicly turned against rational medicine as he had turned against rational theology.

Boerhaave's oration of 1703, "On the Usefulness of the Mechanical Method in Medicine," declared that the ability of reason to control the passions was doubtful. He contradicted one of the supposedly strongest objections to a mechanical account of the body: the "power of the mind over the body." Even if one assumed that the mind could control the body, he argued, "as soon as the capacity of thinking influences our body, every effect it brings about therein is wholly corporeal"; it did not matter whether the first cause of things was corporeal or not, since the physician's task was to perceive the corporeal effect only, "and to scrutinize and

44. Lindeboom, Herman Boerhaave (n. 4), p. 382: "accidit insonti, nec opinanti, aliquid, unde praevidebat impedimenta ambituro Cathedram Ecclesiasticam.” 
guide it" toward health. ${ }^{45}$ A few years later, Boerhaave opened the section on mind in his famous Institutes (first ed. 1708) by remarking that "Man is composed of a Body and Mind, united to each other," but "the Nature of these are very different, and ... therefore, each has a Life, Actions and Affections differing from the other." ${ }^{46}$ As almost everyone agreed, "There is such a reciprocal Connection and Consent between the particular Thoughts and Affections of the Mind and the Body, that a Change in one always produces a Change in the other, and the reverse." ${ }^{27}$ But in an almost exact paraphrase of Descartes, he concluded that "we cannot understand or explain the Manner in which the Body and Mind reciprocally act upon each other from any consideration of their Nature separate; we can only remark by Observation their Effects upon each other, without explaining them." 48

\section{Implications for Medicine}

Whether originated in his study of theology, philosophy, medicine, or something else, Boerhaave brought his doubts about the power of reason to his medical teaching. His outlook is exhibited clearly in the history of medicine with which he began his Institutes. His history lauds sense experience while questioning the use of reason: "From hence it appears that the Art of Physic was anciently established by a faithful Collection of Facts observed, whose Effects were afterwards explained, and their Causes assigned by the Assistance of Reason; the first carried Conviction along with it, and is indisputable; nothing being more certain than Demonstration from Experience, but the latter [i.e., causal reasoning] is more dubious and uncertain." ${ }^{49}$ His heroes, Hippocrates and Harvey, had advanced knowledge farthest because they had paid close attention to "demonstration from experience," whereas Galen had corrupted ancient medical teachings with his elaborate reasoning. To discover truth in physic, all knowledge had to be based on sense experience alone, which meant accounting only for those things "which are purely material in the human Body, with mechanical and physical Experiments." ${ }^{\circ 0}$ Or, as he repeated, discussions of first causes "are neither possible, useful, or necessary to be investigated by a Physician." ${ }^{11}$ The physician should

45. Kegel-Brinkgreve and Luyendijk-Elshout, Boerhaave's Orations (n. 32), p. 114.

46. Boerhaave, Institutes, trans. as Hermann Boerhaave, Academical Lectures (London: W.

Innys, 1743-51), 1: (para. 27), p. 65 (italics in original).

47. Ibid., p. 65.

48. Ibid., p. 66 (italics in original).

49. Ibid., (para. 19), p. 42.

50. Ibid., (para. 25), p. 63 (italics in original).

51. Ibid., (para. 28), p. 71. 
confine himself to materialistic explanations only, based as they were on the demonstrations of anatomy, chemistry, and mechanics via the natural and experimental philosophy. Boerhaave allowed for an immortal soul and God's lawful design of humankind and the rest of creation. Late in his career, he even wrote of a Hippocratic impetum faciens or enormon, a faculty of the soul that bound together soul and body. Even this, however, "was for the physician really not accessible." ${ }^{52}$ Human life might have "a vitalistic beginning" in God's creation, but from then on could be treated entirely according to mechanical principles. ${ }^{53}$

The framework of Boerhaave's Institutes therefore developed quite differently from previous ones. The teaching of the medical institutes had long constituted the basic academic instruction in medicine. It was divided into five parts: the elements of nature, and the natural functions of the body based thereon; pathology; semiotics; hygiene; and therapeutics. What changed most substantially between Boerhaave's textbook and previous ones such as Fernel's was the content of the first part, commonly called physiology (after the Greek púıs, or "nature"). Boerhaave said nothing about the four elements or humors, about formal or final causes, about faculties or powers, or any of the rest of classical teaching. He even-significantly-left out talk about reason (or mind) and the passions. Instead, he explained all that was necessary for a physician to know in terms of observable solids and fluids alone. He dwelt on this experimental physiology, treating the other four parts of the institutes (pathology, semiotics, hygiene, and therapeutics) briefly but also materialistically. He stressed the what and how of medicine rather than the why. The whole work was meant for teaching, being relatively short, composed of elementary propositions that Boerhaave believed to be evident from observation and experiment, upon which he could expand in his lectures to students-which he did somewhat differently every year, according to his latest views. ${ }^{54}$ A couple of years later, he published his textbook on the treatment of disease, titled the Aphorisms (1709), following the example of Hippocrates in more than title by setting down only observations of disease and successful treatment. Again, his theme was how, not why: observation and experience, not reasoning about causes. He also stressed the utilitarian purposes of medicine. Tried experience

52. Antonie M. Luyendijk-Elshout, "Mechanicisme contra vitalisme: De School van Herman Boerhaave en de Beginselen van het Leven," Tijdschrift voor de Geschiedenis der Geneeskunde, Natuurw., Wisk., en Teckniek, 1982, 5: 20-22; quotation on p. 22.

53. Ibid.

54. According to La Mettrie, "Ses Oeuvres classiques, faites pour être expliquées \& pour durer toujours, dénuées de ces explications," were filled in with obscurities by his commentators; "M. Boerhaave l'a pressenti lui-même, ce défaut produit par la breveté nécessaire de son stile," adding oral commentary when he taught (Herman Boerhaave, Institutions . . avec un 
organized and remembered gave one expertise. The end of a medical education was to make the physician an expert, rather than an academic - as someone who could change conditions more than understand the reasons for them.

For the practicing physician, the outlook held by Boerhaave helped to simplify treatment. Particular symptoms of a disease pointed to a particular physiological cause. The disease and its cause would consequently be the same in anyone found to be suffering from the same symptoms. Treatment would then be to modify the corporeal cause of the disease, usually by medicine, sometimes with an accompanying regimen; this treatment would be similar in all suffering the same effects. Age, gender, social class, and other variables might make someone more or less susceptible to particular errant physiological processes-but whether king or queen, duke or peasant, merchant or servant, anyone with a particular disease should be treated for it in the same way as anyone else. Such an outlook stood directly against the classical view that because each person had a different temperament and lived in different circumstances, one needed to consider the probability that the cause of illness in each patient had a different origin, requiring a different treatment. Moreover, rather than counseling a person-by appealing to reason-on how to live better and more healthfully, Boerhaave's medicine made the physician an expert who determined what methods of intervention would return the sick to health.

Boerhaave's exact contemporary at Leiden, Bernard Mandeville, shared his underlying assumptions. An emigrant to England, where he became best known for his satirical Fable of the Bees, Mandeville also took the position that reason could not and indeed should not control the passions, for morality or health. Mandeville's slogan of "private vices, public benefits" meant that the passions themselves led to material wealth and utilitarian improvement. Less well known are the medical sentiments of Mandeville, but they are quite consistent with the view that the physician cannot rely on reason but only on compiling observation and experience. The end of this was to cure disease, not by reasoning with patients to get them to follow learned advice, but by playing on their passions to get them to take the proper medicines. ${ }^{55}$

Boerhaave's outlook had much in common with that of other professors who advocated a new medical outlook. Giorgio Baglivi, of the Collegio della Sapienza in Rome, for instance, had urged: "The two chief Pillars of

commentaire par M. Julien Offray De La Mettrie [Paris: Chez Huart, 1742], unpaginated translator's preface).

55. Harold J. Cook, "Materialism and the Passions: Dr. Bernard Mandeville and the Therapy of the 'Clever Politician,'” J. Hist. Ideas, 1999, 60: 101-24. 
Physick, are Reason and Observation: But Observation is the Thread to which Reason must point. . . . From what has been said, 'tis manifest, that not only the Original of Medicine, but whatever solid Knowledge 'tis entituled to, is chiefly deriv'd from Experience. ${ }^{" 56} \mathrm{He}$, like Boerhaave, was also a great advocate of aphoristical instruction. Boerhaave not only mentioned Baglivi with praise, he also co-opted other favorers of the new philosophy into his work, such as Francis Bacon, Robert Boyle, Isaac Newton, and Thomas Sydenham. Those he sought to emulate all wrote of reason as an aid to observation, experience, and experiment, rather than the other way around. Similarly, Boerhaave's books and orations were not based so much on a system of fundamental principles and their elaboration as on an organizational method by which to present often diverse observations and experiences. In this way, he represents an important element of Enlightenment thinking, which is highly organized but often mistakenly called systematic.

Consequently, Boerhaave thought of himself as the inheritor of a medical viewpoint stretching back no farther than William Harvey and experimental physiology, although he also thought of himself as the inheritor of the facts observed and recorded by any and all authors from Hippocrates onward. The Roman encyclopedist Celsus had famously divided medical thought into three schools: the empiricists, who trusted only to experience and refused to speculate about causes; the methodists, who divided the causes of disease into two (laxity and tension); and the dogmatists, who thought that they could reason to the first causes of events. Even in Boerhaave's day there was a tendency for some medical figures to place their rivals in such a tripartite schema-although, because methodism was hardly an issue until the doctrine of John Brown at the end of the eighteenth century, the schema was ordinarily treated as a dialectic between reason and empiricism. When attacked because he stressed the how rather than why of medicine, Boerhaave's opponents made him out to be an empiricist. The English physician-surgeon Daniel Turner, for instance, attacked Boerhaave's 1729 Treatise on the Venereal Disease as merely empirical because it dealt with treating the symptoms rather than the cause. ${ }^{57}$ "Many ascribe all to Reason, and nothing to Experience; and many again are on the opposite side. Now both sides are

56. Giorgio Baglivi, The Practice of Physick, Reduc'd to the Ancient Way of Observations (London: Printed for Andr. Bell et al., 1704), pp. 9, 15. (This is a translation of his De Praxi Medica. ad Priscam observandi rationem revocanda . . . [Rome: Typis Dominici Antonii Herculis, 1696].)

57. Daniel Turner, A Discourse concerning Gleets (London, 1729). 
equally Criminal; whence spring so many Divisions among Physicians, and such jarrings between the Theory and Practice," wrote Baglivi. ${ }^{58}$

Like Baglivi, Boerhaave refused to think of himself as an empiricist, although he happily criticized dogmatists. Reading critically was as important as, perhaps more important than, simply learning from experience; indeed, Boerhaave himself was by his own admission almost entirely self-taught in medicine through a program of reading alone. He did not think, however, that one could reason from the observable evidence to first causes. Like so many classical empiricists, then, he believed that one had to be content with ultimate causality remaining mysterious-although, unlike them, he was willing to pay close attention to material causes and effects, sometimes called secondary causes; this was "sufficient for all the Purposes of the Physician," he wrote. ${ }^{59}$ Boerhaave's physician was not superior to the empiric because he used reason and the empiric did not, but because of superior experience gathered from any and all sources. He was superior to the dogmatist because he refused to speculate about causes beyond the observable.

Given Boerhaave's position on the limits of reason, it is perhaps not surprising that the most famous-or infamous - materialist of the eighteenth century praised him as his teacher. At first, before he became a materialist, La Mettrie seemed embarrassed that it would be possible to interpret Boerhaave as irreligious. In his translation of Boerhaave's Institutes in 1739 and 1740, he included a "Vie de Monsieur Herman Boerhaave," in which he dealt directly with the question of Boerhaave's silence on first causes. After quoting long passages from Boerhaave's 1730 oration "On Servitude as the Physician's Glory," which speaks about the necessity of the physician understanding and cooperating with nature in order to heal, La Mettrie explained that it would be crude of him to comment on it "in order to make it appear that the learned professor would not recognize other causes of everything that occurs in the world"; Boerhaave recognized that laws are "imprinted on each part of the human body," and in invoking "Nature" he should not be suspected of irreligion. ${ }^{60}$ His life stood as proof that he contemplated the future

58. Baglivi, Practice of Physick (n. 56), p. 10.

59. Boerhaave, Academical Lectures (n. 46), 1:65-66, quotation on p. 66.

60. "J'ai cru devoir rapporter quelques-uns des principaux traits de cette belle $\mathrm{Ha}$ rangue, pour faire voir que ce sçavant Professeur ne reconnoissoit d'autres causes de tout ce qui se passe dans le monde, que le souverain Créateur, \& que c'est à cet Etre des êtres, comme aux Loix qu'il a imprimées à chaque partie du corps humain, qu'il veut que le Médecin se soumette dans tout les cas: \& j'ai entré dans ce détail d'autant plus volontiers, que l'équivoque du mot de Nature, si souvent répété dans ce Discours, n'a pas moins rendu M. Boerhaave suspect d'irreligion" ("Vie de M. Herman Boerhaave," in Herman Boerhaave, 
life. ${ }^{61}$ Ten years later, however, La Mettrie had completed an eightvolume translation with commentary on the Institutes (heavily dependent on Haller's edition and commentary), in which the notes interpreted Boerhaave to be a materialist, and subverted the commentaries of Haller to make the same point. ${ }^{62}$ Perhaps it was in puzzling out how to handle Boerhaave's discussion of the relationship between brain and mind that La Mettrie was led into taking an explicitly materialist position. ${ }^{63}$

Other contemporaries of Boerhaave's also defended views of a machine-like body, most importantly Friedrich Hoffmann at the university of Halle. But like Hoffmann, they usually went much further in their speculations, defending corpuscularianism, Leibnizian motive forces, and other physical hypotheses, which gave some hint about their view of the relation between God and nature. Boerhaave did not. Other professors, such as Hoffmann's colleague, Georg Stahl, found hypotheses about the physical world incomplete without a theory of how reason and God could control the corporeal. ${ }^{64}$ Even to Boerhaave's modern interpreter, Lindeboom, an assessment of Boerhaave's physiology leaves him empty: "It must be conceded . . that Boerhaave's explanation does not satisfy us in any way. It was based upon various anatomical and mechanical factors" rather than "vital qualities." ${ }^{5}$ Given his teachings about the limits of reason, then, Boerhaave's position was not quite the same as other "mechanists." He agreed that all knowledge in medicine came through sensory experience, meaning that one could understand secondary causes. But reason could not lead to a rational understanding of God's nature, will, or plan. Boerhaave's silence on such matters separated him and his followers from the many who wished to make the new science the basis

Institutions de médecine de M. Herman Boerhaave, trans. Julien Offray de La Mettrie [Paris: Huart et Briasson, 1740], pp. 42-43).

61. "Après tout, la vie de Boerhaave, indépendamment de ses écrits, prouve assez ce qu'il pensoit de la vie future" (ibid., p. 44).

62. Ann Thomson, "La Mettrie, lecteur et traducteur de Boerhaave," in Physiologie et médecine, dix-huitième siècle, ed. Mirko D. Grmek and Roselyne Rey (Paris: Presses Universitaires de France, 1991), pp. 23-29.

63. Kathleen Wellman, "La Mettrie's Institutions de medicine: A Reinterpretation of the Boerhaavian Legacy," Janus, 1985, 72: 283-303, argues that La Mettrie's work with the Boerhaavian text helped to make La Mettrie into a materialist.

64. See esp. Johanna Geyer-Kordesch, "Passions and the Ghost in the Machine: Or, What Not to Ask about Science in Seventeenth- and Eighteenth-Century Germany," in The Medical Revolution of the Seventeenth Century, ed. Roger Kenneth French and Andrew Wear (Cambridge: Cambridge University Press, 1989), pp. 145-63.

65. Gerrit A. Lindeboom, "Boerhaave's Concept of the Basic Structure of the Body," Clio Med., 1970, 5: 203-8, quotation on pp. 207-8. 
for a natural theology. ${ }^{66}$ His critics noticed: in Apologia pro vera et saniore philosophia (1718), the Franeker professor R. Andala accused Boerhaave of being a skeptic and an atheist. ${ }^{67}$ Perhaps sensitivity to such criticisms helps explain why Boerhaave's followers went to such lengths to detail his good and Christian character.

In the end, then, Boerhaave was not a thoroughgoing materialist, only a medical one. His private faith, which gave him the daily joy and strength to work terribly hard despite the carping of his critics, clearly had a profound importance for his life-but not for his medicine. His attack on prideful reason and his support for observation and experience of the material world may have been common, but they were not without serious and controversial implications. Perhaps Alfred North Whitehead put it best when he remarked about the "rise of modern science" in the sixteenth and seventeenth centuries that "it is a great mistake to conceive this historical revolt as an appeal to reason. On the contrary, it was through and through an anti-intellectualist movement." 68 Perhaps he overgeneralizes. But Whitehead reminds us that while many early modern savants backed off from full-fledged materialism in their personal faith, their new philosophy threatened to make reason into mere instrumentalist logic-with knowledge simply a calculus of outcomes, a gathering and summing of information about the material world, a cheap substitution for the Reason that counseled humankind on how to become closer to the true source of all being. To its advocates, this anti-intellectualist movement allowed for inspiration arising from the experience of things as well as rigorous investigation. But to its opponents, the notion that reason could neither understand the causes of nature nor control the bodily passions threatened, not because it lurked in the dark but because it brought such open successes as the teachings of Herman Boerhaave.

66. Also see Shirley A. Roe, "Voltaire versus Needham: Atheism, Materialism, and the Generation of Life," J. Hist. Ideas, 1985, 46: 65-87.

67. Sassen, Geschiedenis van de Wijsbegeerte (n. 33), p. 224.

68. Alfred North Whitehead, Science and the Modern World (1925; reissued New York: Free Press, 1967), p. 8. Also see Gary Hatfield, "Metaphysics and the New Science," in Reappraisals of the Scientific Revolution, ed. David C. Lindberg and Robert S. Westman (Cambridge: Cambridge University Press, 1990), pp. 93-166. 